\title{
Conflict Management and Resolution: Can We Agree? 1
}

Meredith Taylor $^{2}$

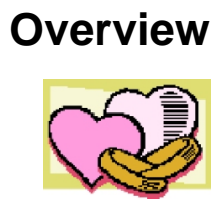

In a successful marriage, couples have more positive than negative interactions. There are more times of talking cheerfully than of talking angrily. Positive interactions and good times help couples feel loved and respected. Negative interactions and bad times lead to feelings of hurt, anger, and sadness.

\section{Perspective: What is Your Perspective?}

All people are different. We each have different likes and dislikes, beliefs, values. These differences make up our individual perspective. Perspective is the way people consider things: it is your point of view, your frame of reference.

Your perspective is influenced by childhood experiences: your relatives, your upbringing, your schooling, and other life experiences.

Different perspectives bring excitement to courtships, relationships, and to marriage. Differing perspectives can also cause conflict and disagreement. The goal for couples is to see things the way the other person does. Get more information without judging your partner and the situation. Ask questions and talk to come to understand each other's perspective.

\section{Take This Visual Test}

Take a look at this graphic:

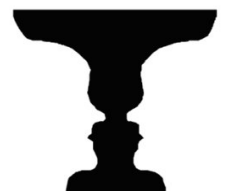

What do you see? Some people see two people talking. Some see a vase or pedestal. Usually a person sees one first and has to really study the drawing to see the other. Some individuals must have the outline of the other image traced before they can find it.

This example represents two very different perspectives of a single drawing. Imagine how complicated it can get when one couple has two perspectives as they deal with problem areas in their marriage.

1. This document is FCS2181, one of a series of five publications that are part of Before You Tie the Knot, a marriage preparation curriculum of the Family Youth and Community Sciences Department, Florida Cooperative Extension Service, Institute of Food and Agricultural Sciences, University of Florida. Original publication date November 1, 2001. Revised November 2, 2005. Reviewed Visit the EDIS Web Site at http://edis.ifas.ufl.edu.

2. Meredith Taylor, M.S., Suwannee County Extension Director, Cooperative Extension Service, Institute of Food and Agricultural Sciences, University of Florida.

The Institute of Food and Agricultural Sciences (IFAS) is an Equal Opportunity Institution authorized to provide research, educational information and other services only to individuals and institutions that function with non-discrimination with respect to race, creed, color, religion, age, disability, sex, sexual orientation, marital status, national origin, political opinions or affiliations. U.S. Department of Agriculture, Cooperative Extension Service, University of Florida, IFAS, Florida A. \& M. University Cooperative Extension Program, and Boards of County Commissioners Cooperating. Larry Arrington, Dean 


\section{The Role of Conflict}

The way a couple deals with conflict is a powerful predictor of marital success. Good news: it is also an area in the marriage that can be changed. Conflict can be a way of getting to know each other and each perspective better. Happier, more stable marriages are created by sharing respect, power, and decision-making.

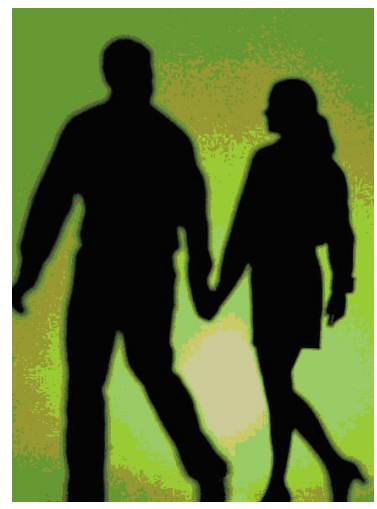

\section{Positive Aspects Of Conflict}

There are positive and negative aspects of conflict. Positive or good outcomes of conflict include the following:

\section{Conflict can help couples recognize discontent.}

A conflict signals that at least one partner is unhappy. It is similar to physical pain or a physical sympton, when you take action in order to feel better. Conflict can let you know something is wrong and needs attention.

\section{Conflict can result in a change for the better.}

Disagreeing about how to handle a situation helps you figure out your own way of working through problems as a couple.

\section{Conflict can produce new ideas and improvements.}

When you try to see things from your partner's point of view, you might come up with entirely new thoughts.
For example, let's say you are disagreeing about how to spend $\$ 50$ you've received as a wedding present. One of you wants to spend it on the wedding. The other wants to spend it on the home.

Try setting both of those wants aside. Talk out ideas for spending it that would please you both. Consider all options you both mention. Be open to looking for a way that you can agree. Who knows what might happen? You may both be happy with something else-like a special night out for your one month anniversary.

\section{Conflict can foster unity and understanding.}

Situations that are upsetting can help you learn more about each other. You learn about each other's strengths and weaknesses. What you learn can bring you closer together. This produces the good feeling of making up. Be hard on the problem and soft on each other.

\section{Conflict can bring about behavior changes.}

As a couple, you learn which words and actions cause arguments. Each can purposely change, so he or she doesn't say or do those things. Work to make the relationship prosper. Each partner can make individual changes in order to create harmony instead of conflict.

\section{Negative Aspects Of Conflict}

It is not a disagreement itself, but how you deal with the conflict that makes it helpful or hurtful. Most important is how each partner feels about the interaction. Those feelings result from both negative and positive aspects of conflict. Negative or less desirable aspects of conflict include the following:

\section{Conflict can increase accusations and threats.}

These can start in the early part of the argument and get worse. The first three to five minutes of interaction determine the direction the argument will take. Strong accusations can turn into a shouting match. Avoid accusations. Instead, bring up concerns 
with a calm tone of voice. A quieter voice soothes irritation and anger.

\section{Conflict can begin with one issue and grow into many issues.}

The argument starts snowballing and referring back to other times when you've been unhappy, angered, or annoyed. It gets harder to focus on the present problem. It gets even harder to focus on a solution. Avoid the temptation to bring up the past. Instead, keep your comments focused on the current issue.

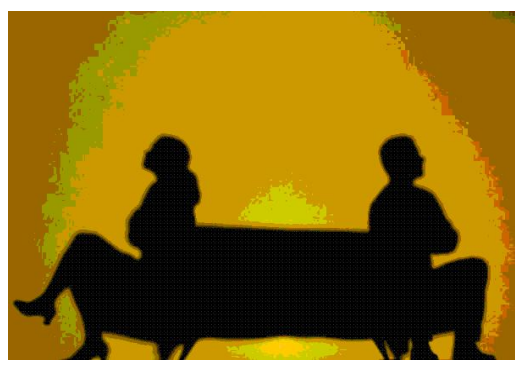

\section{When conflict continues to go on and on, specifics change to generalizations.}

Couples begin to say to each other, "you always...or, you never..." Generalizing makes you less flexible and less able to think of ways to solve the problem. Instead, talk about specific concerns or behaviors.

\section{As conflict continues, the number of people involved grows larger.}

Do you keep telling people your problem in order to find someone on your side? Ask yourself, "What is my motive? Why am I telling this?" Encouraging friends and relatives to take sides may feel good in the short-term. In the long-term, you and your spouse will make up, and then both sides will feel uncomfortable.

\section{When conflict is not being resolved, it can lead to a desire to seek revenge.}

You may want to "get back" at one another and sabotage one another rather than work through the situation together. Outsiders can fuel the conflict with comments like "Don't let him get away with this" or "You're not going to let her boss you, are you?" Instead, talk honestly with your spouse. Talk about working through the problem together as a couple.

Work through conflict so that it strengthens your relationship. Build on the positive. And compliment yourselves when you have created a good solution to the problem that was causing conflict.

\section{Emotional Flooding}

The strong words and actions of one spouse can be so overwhelming that the other one feels flooded. The negative expressions cause a feeling of mental numbness. Flooding also creates symptoms of physical stress such as increased heart rate, sweating, and shortness of breath.

When you are flooded, your reactions become emotional instead of logical. Feeling out of control, you are unable to continue talking and trying to solve the problem. A partner who is emotionally flooded might leave the room, tune out, start yelling, or become violent.

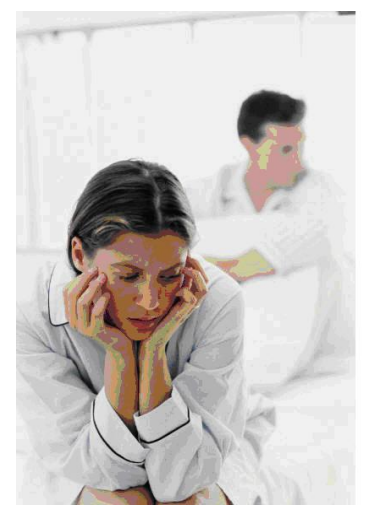

Flooding is especially a problem when partners have a different response to it. One may want to "talk now," but this creates more flooding for the other. One may take longer to recover from flooding. She or he may want to get away from it and then come back to talk. Violence is never a solution to conflict!

To control flooding, avoid being critical, or sarcastic or accusing. Stop arguing before the conversation heats up and causes emotional flooding. Instead, use "I" messages. For example: "I get 
upset when..." instead of "You upset me when..."

Do what you can to calm yourself. Try deep

breathing. Call time out, and allow enough time for

cooling down. Realize that one of you may be ready to talk again before the other is ready.

\section{Problem Solving}

Conflict resolution is problem solving. There are five basic steps to problem solving:

\section{State the Problem.}

Use "I" messages to state the problem. For example: "I get angry when the garbage piles up, because it attracts bugs." Take turns talking and listening. Share ideas rather than give advice.

\section{Look for Areas of Agreement.}

Identify areas of agreement. Even small points of agreement are a positive thing. For example: "We both want to avoid using bug sprays."

\section{Explore Alternatives.}

Talk about different ways to solve the problem. You'll have a greater chance of finding the best solution. All requests should be for change in behavior, not attitudes. You can't ask each other to feel differently. For example: "We can take care of the garbage on alternating weeks. I will start first or would you rather start this week?". "I'll do the garbage and you do the sweeping."

\section{Try a Solution.}

Be specific about what will be tried. Avoid referring to what happened in the past. Stay in the present and the future. For example, "I will check the garbage every day after dinner."

\section{Evaluate Results.}

If the solution doesn't work, go through the steps again. Try a different solution. Set a time for the next discussion. For example: "Let's talk about the garbage situation Tuesday night."

Joint problem-solving, doesn't mean one person wins and the other loses. Work toward finding a Win-Win solution, where both feel satisfied. The goal is to understand each other. Compromise and resolve; you do not have to agree. Some couples call it "agreeing to disagree". They are committed to the relationship and overlook disagreements.

Always strive to build on the positive aspects of your relationship. A commitment to sharing respect, power and decision-making makes for the happiest, most stable marriages.

\section{Resolving Conflict: A Summary}

- Conflict happens, because we are human.

- The marriage relationship comes first and is worth lots of effort to preserve.

- Avoid an "I win; you lose" attitude. It is possible for both to win- at least in part -and no one has to lose.

- It is easier to settle things when you both have the same information about the problem.

- Remember that each person has information through his or her own perspective. Check out the facts!

- Decide on a common goal, such as "rest and relax on vacation" or "see as many sights as we can."

- Be honest and direct with each other.

- Accept responsibility for your own feelings.

- Confront and deal with problems openly instead of avoiding or hiding from them.

- Agree on ground rules or agreements for handling conflict as a couple.

- Conflict itself is not the main issue; how you deal with conflict is most important. 


\section{References}

Gottman, John. 1994. Why Marriages Succeed

or Fail. Simon \& Shuster, Inc., NY, NY. 234pp.

Gottman, John and Nan Silver. 1999. The Seven Principles for Making Marriage Work. Crown

Publishing, NY, NY. 271pp.

Leadership Suwannee '95: "When There is Disagreement ... How to Fight Fair". Patsy Holmes, North Florida Mental Health Center. Lake City, FL. Presentation.

Leadership Suwannee '96: "Conflict Resolution --As a Leadership Skill”. Patsy Holmes, White Foundation, Gainesville, FL. Presentation.

\section{The Role of Conflict in a Relationship}

In this segment of the Florida Marriage Preparation series, couples are encouraged to look at the importance of learning to negotiate conflict--and learn its positive and well as its negative aspects. Other related publications besides Conflict

Management and Resolution--Can We Agree? include: Your Money Matters, Can We Talk? Improving Couple Communication, Couples Considering Parenthood, Couples Considering A Blended Family, and So You are Getting Married in Florida!

Click here to print or view the entire publication. 